\title{
ガウンの素材違いによる抗がん剤透過の危険性の検討
}

\author{
志田敏宏 ${ }^{* 1}$, 高橋修二 ${ }^{1}$, 小林聖子 ${ }^{1}$, 加藤祐太 ${ }^{1}$, 西村雅次 ${ }^{2}$, 金野 昇 $^{1}$, 豊口禎子 ${ }^{1}$, 白石 正 $^{1}$ \\ 山形大学医学部附属病院薬剂部 ${ }^{1}$, 社会福祉法人恩賜財団済生会山形済生病院 ${ }^{2}$
}

\section{Assessment of the Risk of Anticancer Drug Permeability through Gowns Made of Various Materials}

\author{
Toshihiro Shida*1, Shuji Takahashi ${ }^{1}$, Seiko Kobayashi ${ }^{1}$, Yuta Kato', Masatsugu Nishimura ${ }^{1}$, \\ Noboru Konno ${ }^{1}$, Teiko Toyoguchi ${ }^{1}$ and Tadashi Shiraishi ${ }^{1}$ \\ Division of Pharmacy, Yamagata University Hospital ${ }^{1}$, \\ Department of Pharmacy, Yamagata Saisei Hospital ${ }^{2}$
}

\author{
$\left[\begin{array}{l}\text { Received May 20, } 2010 \\ \text { Accepted November 30, } 2011\end{array}\right]$
}

\begin{abstract}
Many drugs used in cancer treatment are considered hazardous to healthcare workers. These drugs require special handing because of the health risk associated with direct exposure. However, occupational exposure to antineoplastic drugs is common in many hospitals. Gowns are worn as protective garments. Guidelines recommend the use of lintfree gowns made of low-permeability fabric, such as polyethylene-coated materials. In this study, we compared the permeability properties of various polypropylene-based protective gowns against a battery of anticancer drugs (fluorouracil and paclitaxel). We determined the risk associated with the use of inappropriate gowns. Permeability, humidity, and repellency of 5 unwoven fabric gown samples were determined according to the Japanese Industrial Standards (JIS). The results show that none of the samples of unwoven fabric gowns provided the same level of protection as the polyethylene-coated gowns. In addition, low-permeability gowns, especially those with a high repellency, may pollute the working area when contaminated. The risk of occupational exposure was thought to be higher in hospitals where inappropriate gowns are worn. Therefore, individuals being exposed to hazardous drugs should adhere to the guidelines regarding protective clothing in order to minimize occupational exposure.
\end{abstract}

Key words — gown, anticancer drug, occupational exposure, permeability

\section{緒言}

抗がん剂の安全な取り扱いの基本は防護であ り，皮膚，気道および口腔の 3 つの経路からの抗 がん剂の進入を阻止しなければならない。日本病 院薬剤師会では抗がん剂を取り扱う医療従事者の 職業性曝露を防止するため, 取り扱いに関するガ イドラインを制定しており，抗がん剤調製作業時 には，ガウン，マスク，キャップ，防護メガネお よび手袋の着用を推奨している ${ }^{1)}$. ガウンは体幹 および上腕に抗がん剂が付着するのを防止し皮膚
からの抗がん剤の進入を阻止するために必要な防 護具である。また，抗がん剂の調製作業時のガウ ンは，滅菌済みのディスポーザブル製品で背開き であり，長袖で袖口があり手袋を着用するとき袖 口の上に被せられる形状であること, さらに前面 および両腕に薬剤不透過処理が施され, 污染時に は早急に取り替える必要があるが, 内部へ容易に 浸透しないようなタイプを選ぶことが推奨されて いる。しかし，抗がん剤を扱う施設において，医 療従事者の職業被曝が報告されており ${ }^{223)}$, さら に，防護具を適切に使用していない施設が数多く

*山形県山形市飯田西2-2-2 
認められるとの報告がある ${ }^{3)}$.そのため，抗がん 殽取扱者の曝露を低減化するために防護具や調製 環境を整えなければならないが, 防護具を着用し， 閉鎖系注入器具を導入している施設においても, 調製者の被曝や，抗がん剂調整室の污染があった ことが報告されており ${ }^{4)}$ ，抗がん剂被曝に対する リスクが高いことが示唆される，そこで，本研究 は，ガウン素材に対する抗がん剂の透過耐性およ び反発性を検討し，不適切な素材のガウンを使用 することによる危険性を検討した。

\section{方 法}

\section{1. 材料}

山形大学医学部附属病院または山形済生病院に て使用経験のある，素材および性質の違う 5 種類 のガウンの未使用切片を実験に使用した（表 1）. また，注射剤・抗がん薬無菌調製ガイドラインの 条件を満たすガウンを推奨ガウンとした．抗がん 凨は，水性溶媒を用いたフルオロウラシル注射剂 （5-FU 注 ${ }^{\circledR}$ ，以下 5-FU と略す）扔よび油性溶媒 を用いたパクリタキセル注射剂（タキソール注 ${ }^{\circledR}$, 以下 PTX と略す）を試験液とした。

\section{2. ガウンの持続耐液体浸透性試験}

ガウンの透過耐性は，透過量および湿潤量にて 評価した。 未使用ガウンの切片 $(5 \mathrm{~cm} \times 5 \mathrm{~cm})$ をろ紙 $(5 \mathrm{~cm} \times 5 \mathrm{~cm})$ 上に載せ重量を測定した $(\mathrm{a}$, b), 次に $0.5 \mathrm{~mL}$ の試験液をガウン切片上に滴下 し, 重量測定後 (c)，1，3 および 8 時間放置した. その後, 予め重量を測定しておいたシリンジ $(\mathrm{d})$ にてガウン上の試験液を吸引した（e)。また， PTX はシリンジで吸引することが困難であった ため, 吸引できなかった試験液はろ紙で吸収した。 試験液吸引後のシャーレ, 万紙およびガウン切片 の重量を測定し（f,g），透過量および湿潤量を 図 1 に示した計算式より算出し，ガイドライン 推奨のガウン（以下，推奨ガウンと略す）と比較 した（図1)。それぞれのガウンに対して透過量 および湿潤量を 6 回測定した。なお, 試験液滴 下後の放置時間は，ガイドラインのガウン交換時 期および薬剤師の勤務時間等を考慮し，1，3 お よび 8 時間とした。さらに, 滴下する試験液量は, $5 \mathrm{~cm} \times 5 \mathrm{~cm}$ のガウン切片上に留まり，ろ紙また はシャーレを直接濡らさない量を検討し, $0.5 \mathrm{~mL}$ と設定した。

\section{3. 定性試験}

持続耐液体浸透性試験において一定時間放置 後，ろ紙に透過したフルオロウラシルまたはパク リタキセルの有無を分光光度法により確認した。 細かく切ったろ紙および蒸留水 $3 \mathrm{~mL}$ を遠沈管に 入れ振とうし，万紙に吸収された試験液成分を抽 出した，その後，抽出液を注射筒にて採取し，メ ンブランフィルター（Millex ${ }^{\circledR} 33$ mm Sterile Filter Unit）にて異物を除去した。生成した抽出液の吸

表 1 実験に使用したガウンの素材と製法

ガウン $\mathrm{A} \sim \mathrm{D}$ および推奨ガウンの生地の構造, 素材, 製法, 撥水性および耐アルコール性について示した

スパンボンド，メルトブロー，サーマルボンド，スパンレースはそれぞれ不織布の製造方法である.

\begin{tabular}{|c|c|c|c|c|}
\hline & 生地の構造 & 素材および製法 & 撥水性*1 & "耐アルコール*2 \\
\hline A & 1 層性不織布 & PP スパンボンド & + & - \\
\hline B & 3 層性不織布 & $\mathrm{PP}$ スパンボンド / PP メルトブロー／PP スパンボンド & + & $\begin{array}{l}\geqq 8 \text { 級 } \\
\text { (耐油加工) }\end{array}$ \\
\hline $\mathrm{C}$ & 3 層性不織布 & PP サーマルボンド／PE フィルム／レーヨンスパンレース & + & 不明 \\
\hline $\mathrm{D}$ & 4 層性不織布 & $\begin{array}{l}\mathrm{PP} \text { スパンボンド／PP メルトブロー／PP メルトブロー／ } \\
\mathrm{PP} \text { スパンボンド }\end{array}$ & + & 8 級 \\
\hline 推奨 & $\begin{array}{l}\text { ポリエチレン } \\
\text { コート不織布 }\end{array}$ & PE でコーティングされた PP 性不織布 & + & 不明 \\
\hline
\end{tabular}

推奨：ガイドライン推奨のガウン, PP：ポリプロピレン, PE：ポリエチレン

* $1:$ 製品パンフレットへの記載の有無

* 2：耐アルコール性 : パンフレットに記載された值（JIS L 1912 医療用不織布試験法で測定した值） 


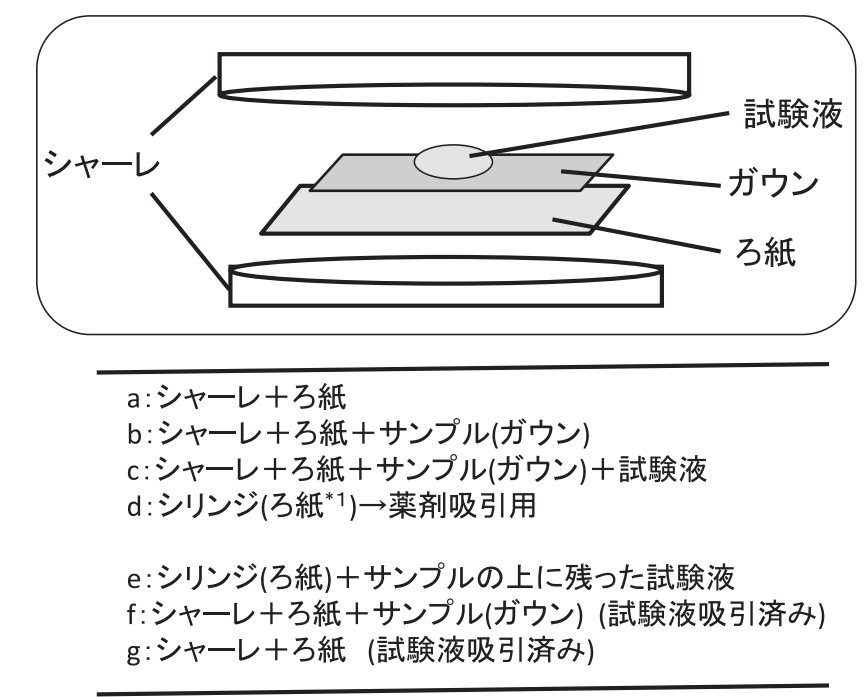

\section{透過量=g-a}

湿潤量 $=(c-b)-(e-d)-(g-a)$ 全液一残液一透過した液
*1: パクリタキセル注射液を吸引する際,

シリンジで吸引できなかった液を吸収するため使用

図 1 持続耐液体浸透性試験

未使用ガウン切片, 万紙を図のように設置し, 試験液をガウン切片上に滴下 し， 1，3㧍よび 8 時間放置した。 その後，万紙掞よびガウン切片の重量変 化より，透過量および湿潤量を図に示した計算式より算出した。

光度を分光光度計（HITACHI U2000）にて測定し， 標準品と波長を比較した。標準品の波長はフルオ ロウラシルが $265 \mathrm{~nm}$ 付近, パクリタキセルが $230 \mathrm{~nm}$ 付近とした.

\section{4. 耐液体浸透性および反発性試験}

図 2 の試験系を用い，45に傾斜させた筒にろ 紙 $(3 \mathrm{~cm} \times 11 \mathrm{~cm})$ および予め重量を測定した ガウン切片 $(3 \mathrm{~cm} \times 12 \mathrm{~cm}, \mathrm{a})$ を順番に密着させ, $5 \mathrm{~mL}$ の試験液を 10 秒かけて細流にて放出し，予 め重量を測定したビーカー（b）にて回収した. 細流は $10 \mathrm{~mL}$ のシリンジを用い, 試験液充填時 および放出後のシリンジの重量を測定した（c, e). 放出終了 30 秒経過後のガウン切片の重量 $(d)$ およびビーカーに回収された試験液の重量（f） から，浸透指数抒よび反発指数を図 2 に示した 計算式より算出し耐液体浸透性㧍よび液体反発性 を評価した。実験プロトコールは日本工業規格の 耐液体浸透性試験（JIS T 8115: 2005）をもとに作 成した．また，それぞれのガウンについて，浸透 指数㧍よび反発指数を 4 回測定した.

\section{5. 統計解析}

データは平均值士標準偏差として表した.また， 持続耐液体浸透性試験および耐液体浸透性試験に おいて, 2 群間の比較は student の $t$ 検定を用いた. 有意水準は危険率 $1 \%$ 未満とした。

\section{結果}

\section{1. 持続耐液体浸透性の比較}

推奨ガウンを基準として, 各ガウンに対する試 験液の透過量および湿潤量を比較した。 5-FUの 透過量は推奨ガウンと比較し, すべてのガウンで 有意に高かった，定性試験では，ガウン A では 一時間後, ガウン Dでは 3 時間後より検出された. ガウン $\mathrm{B}$ および $\mathrm{C}$ は 8 時間後にわずかなピーク が検出された。 また，推奨ガウンの 5-FU の透過 量は時間経過とともに徐々に増加し，8時間後に は $19.9 \mathrm{mg} / 0.5 \mathrm{~mL}$ であり， 8 時間後にフルオロウ ラシルの透過が検出された。 また，湿潤量におい て, ガウン $\mathrm{A}$ 以外は 1 時間後までは推奨ガウン と同等の湿潤量を示したが，時間経過とともに湿 潤量の増加が認められ，3 時間後にガウン $\mathrm{B}$ およ 

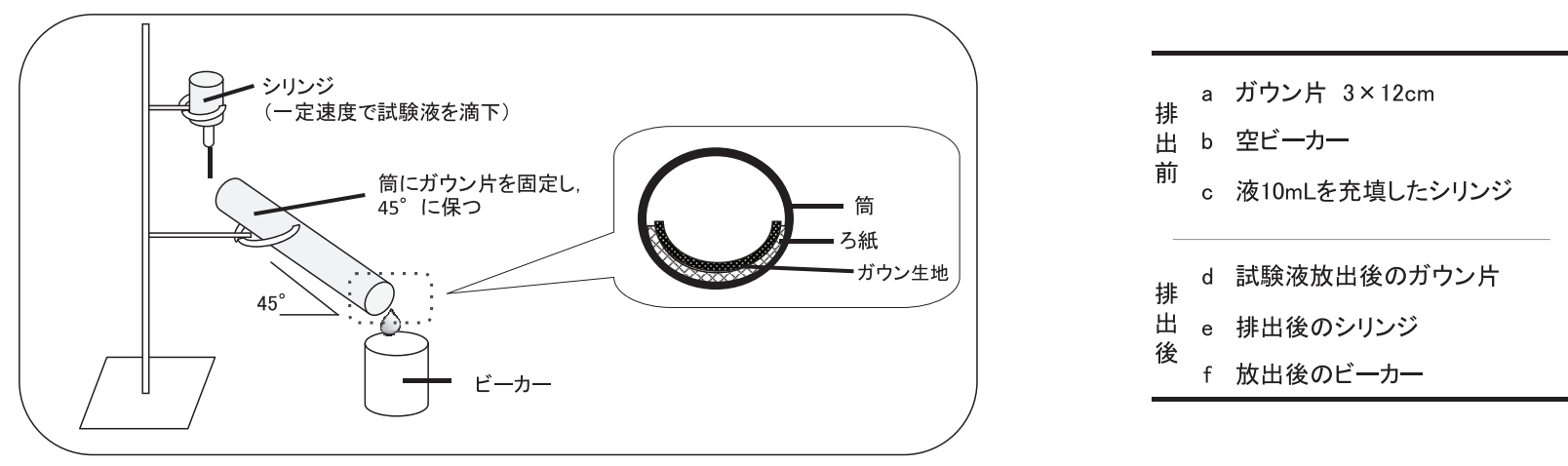

総液量 $(M t)=c-e$

反発された液量 $(M r)=f-b$

湿潤量 $=\mathrm{d}-\mathrm{a}$

ろ紙に吸収された試験液量 $(M p)=M t-M r-$ 湿潤量

浸透指数 $(\mathrm{P})=\mathrm{Mp} / \mathrm{Mt} \times 100$

反発指数 $(\mathrm{R})=\mathrm{Mr} / \mathrm{Mt} \times 100$

図 2 耐液体浸透性試験

$45^{\circ}$ に傾斜させた筒にろ紙ガウン切片 $(3 \mathrm{~cm} \times 12 \mathrm{~cm}, \mathrm{a})$ を順番に密着させ, $5 \mathrm{~mL}$ の試験液を 10 秒かけ て細流にて放出した．放出終了 30 秒経過後のガウン切片の重量およびビーカーに回収された試駼液の重 量から, 浸透指数㧍よび反発指数を図に示した計算式より算出した.

びCにおいて有意差が認められた。その後, 8 時 間後はガウン $\mathrm{B}$ および $\mathrm{C}$ ともに推奨ガウンと比 較して同等の湿潤量であった。またガウン D は 3 時間後までは推奨ガウンと同等の湿潤量であった が， 8 時間後に有意差が認められた。ガウン A は 経過時間ごとにばらつきが大きかったが，8時間 後には推奨ガウンと比べ有意に湿潤量が多かっ た．推奨ガウンは経時的な湿潤率の増加が認めら れ, 8 時間後には $39.8 \mathrm{mg} / 0.5 \mathrm{~mL}$ であった（図3）.

一方，PTXにおいて，ガウン A， ガウン D は PTX を完全に透過させたのに対し，ガウン B の 透過量および湿潤量ともに経時的な増加が認めら れたが，8時間後まで推奨ガウンと差は認められ なかった。しかし，3時間後にろ紙から PTXが 検出された。 ガウン C は 1 時間後には推奨ガウ ンと比較し有意に透過量が多く, 1 時間後より PTX が検出された。また，ガウンCはPTXの生 地内への湿潤が多く, 滴下したPTX のほとんど を吸収した．推奨ガウンは透過量の経時的変化は ほとんどなく, 8 時間経過後は $1.3 \mathrm{mg} / 0.5 \mathrm{~mL} て ゙$ あった，湿潤量は経時的な増加が認められ，透過 量 8 時間後に $173 \mathrm{mg} / 0.5 \mathrm{~mL}$ に達した（図 4).万 紙への PTXの透過は認められなかった。

\section{2. 耐液体浸透性および反発性の比較}

推奨ガウンを基準として, それぞれのガウンの 各試験液に対する耐液体浸透性㧤よび反発性を比 較した．5-FU 注射液については，ガウン A の反 発指数が $76.0 \%$, 浸透指数が $23.4 \%$ であり, 透過 が認められた。これに対し, ガウン $\mathrm{B}$ および $\mathrm{C}$ では $99 \%$ 以上の反発指数で, 浸透指数もほぼ $0 \%$ に近い值であり, 推奨ガウンと同等の反発性を示 した。 ガウン D は $98.5 \%$ の反発指数であったが, 推奨ガウンと比較すると有意に低かった（図 5).

また，PTXに対しては，ガウン A は PTX 滴下 と同時に透過し, 反発指数の測定は不可能であっ た. ガウン B は $98.2 \%$ の反発指数であり, 推奨 ガウンと比較し有意に高く, 浸透もほとんど認め られず，推奨ガウンより有意に低かった。ガウン C の反発指数は $91.4 \%$ であり, 推奨ガウンと比較 すると有意に低い值であった，また，浸透指数は $2.8 \%$ であり, 推奨ガウンと同等であった。ガウ ン D は持続耐液体浸透性試験では完全に浸透し たが, 反発指数抒よび浸潤指数は $88.7 \%$ および 4.2\%であった（図6）. 

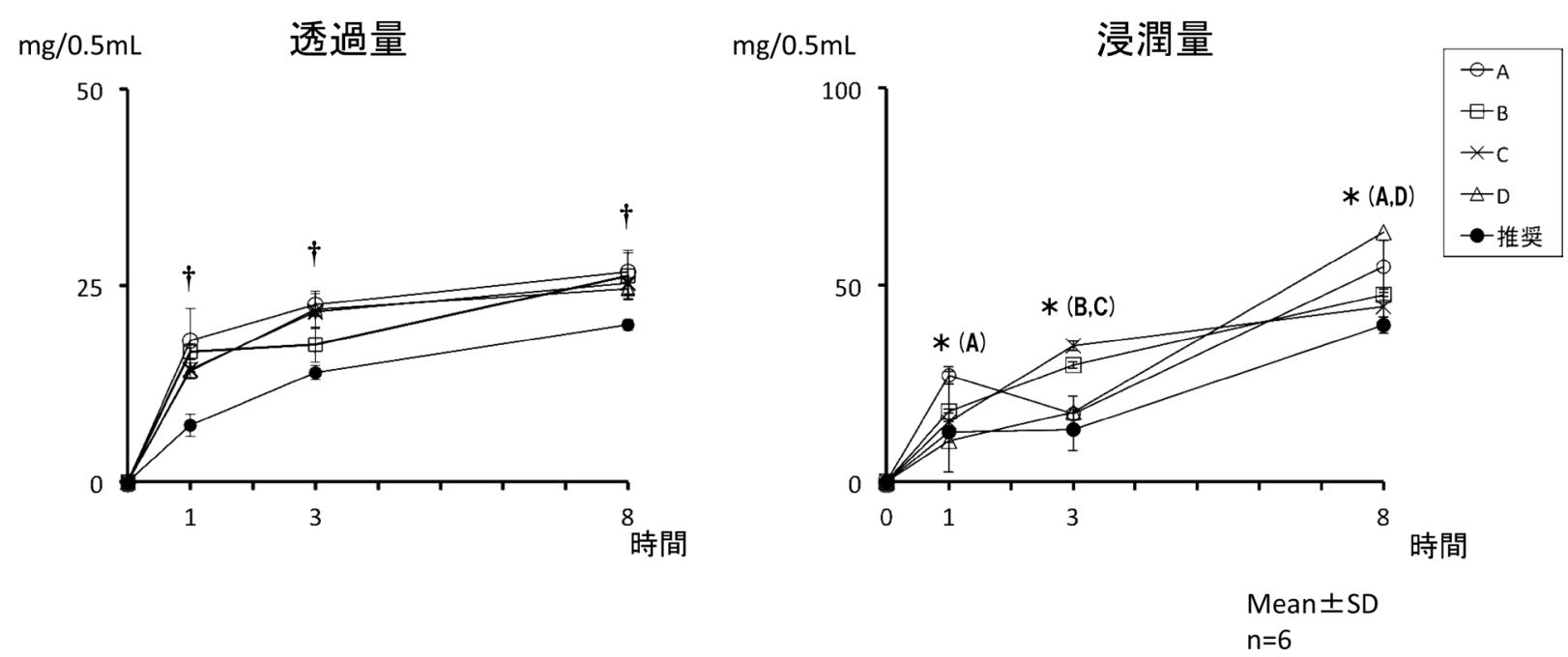

† : 推奨ガウンと比較してすべてのガウンで $p<0.01$

* : 推奨ガウンと比較してカッコ内のガウンでp $<0.01$

図 3 フルオロウラシル注射液の透過量および湿潤量の経時的変化

推奨ガウンを基準として, 各ガウンの 5-FU に対する透過量および湿潤量の経時的変化を比較した.
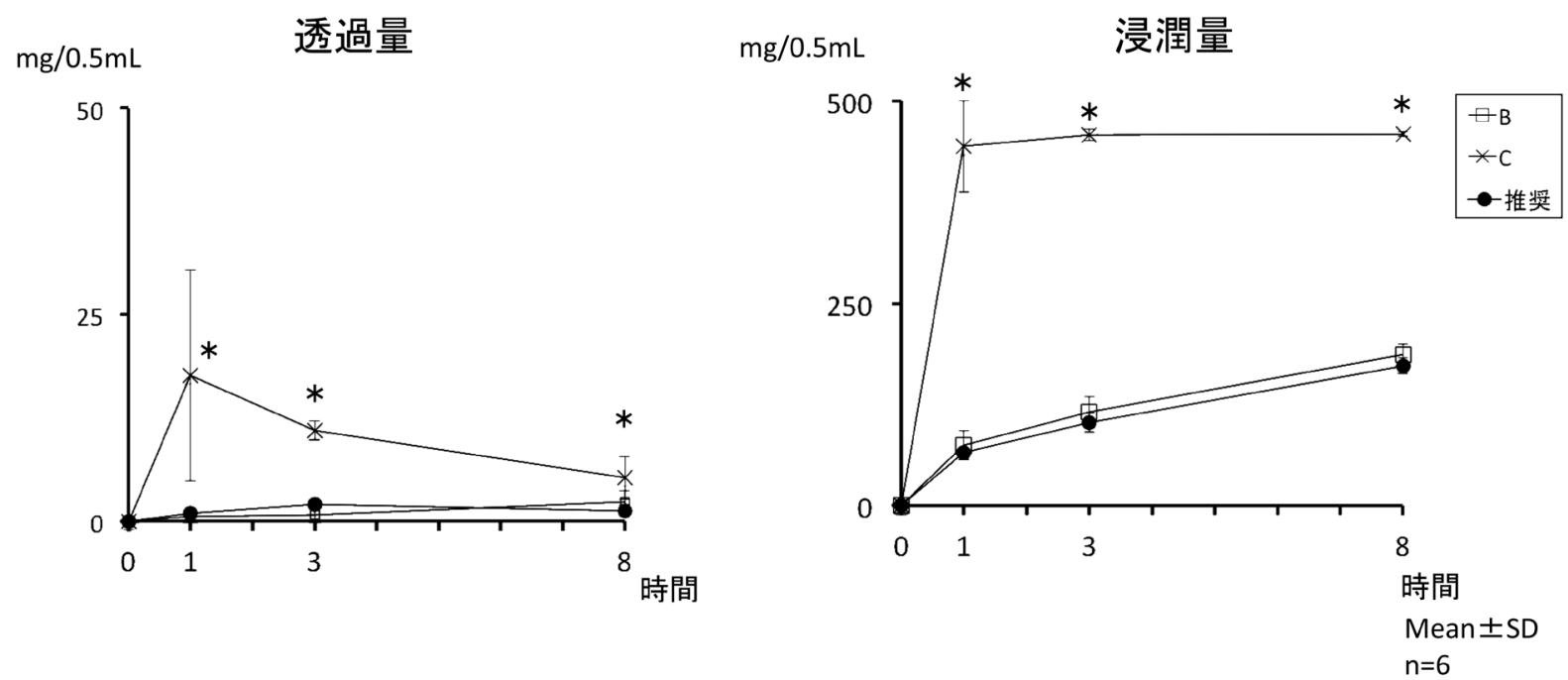

*: 推奨ガウンと比較して $\mathrm{p}<0.01$

ガウンAおよびDは測定不可

図 4 パクリタキセル注射液の透過量および湿潤量の経時的変化

推奨ガウンを基準として, 各ガウンの PTX に対する透過量および湿潤量の経時的変化を比較した.

\section{考察}

抗がん剂の被曝は吸入および皮膚接触が最も可 能性の高いルートであることが，日本病院薬剤師 会注射剤・抗がん薬無菌調製ガイドラインで示さ れており，十分な防護対策が必要である。ガウン は皮膚接触を防護するうえで必要不可欠であり， ガイドラインにおいても薬剤不透過性の素材であ
ることが推奨されている。特にポリエチレンで コーティングされた生地を用いたガウンが推奨さ れており ${ }^{1,5 \sim 6)}$, 今回の実験結果からも, 推奨ガ ウンより優れた防護性能を有する不織布ガウンは ないと考えられ, 推奨されていないガウンを使用 することの危険性が示唆された.

また，日本病院薬剤師会のガイドラインでは， 抗がん剂調製時のガウンは 3 時間ごとに交換し, 
浸透指数

$\%$

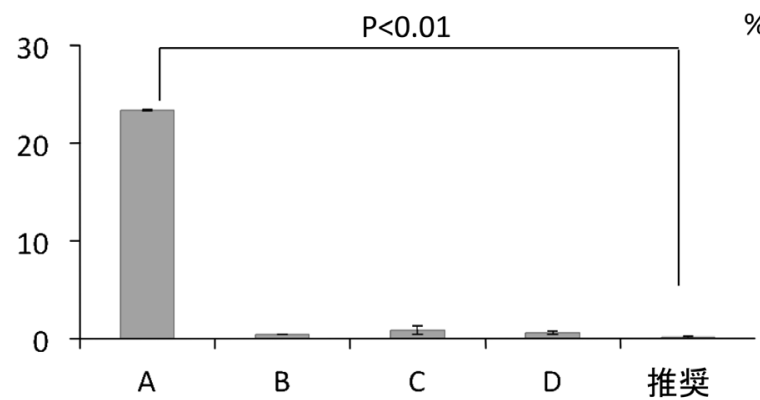

反発指数

$P<0.01$

$\%$

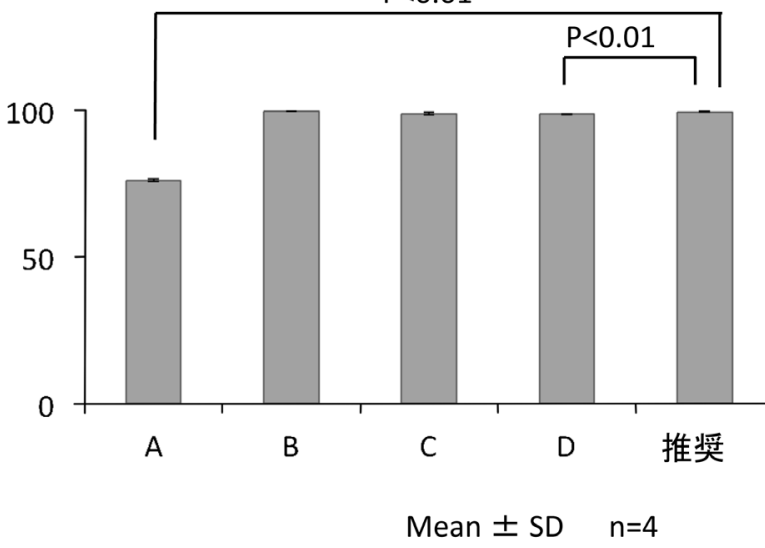

図 5 各ガウンのフルオロウラシル注射液に対する浸透指数および反発指数 推奨ガウンを基準として，それぞれのガウンの 5-FUに対する耐液体浸透性および反発性を比較した. グラフは平均值士標準偏差で示し, 危険率 $1 \%$ 以下を有意差有りとした.

浸透指数

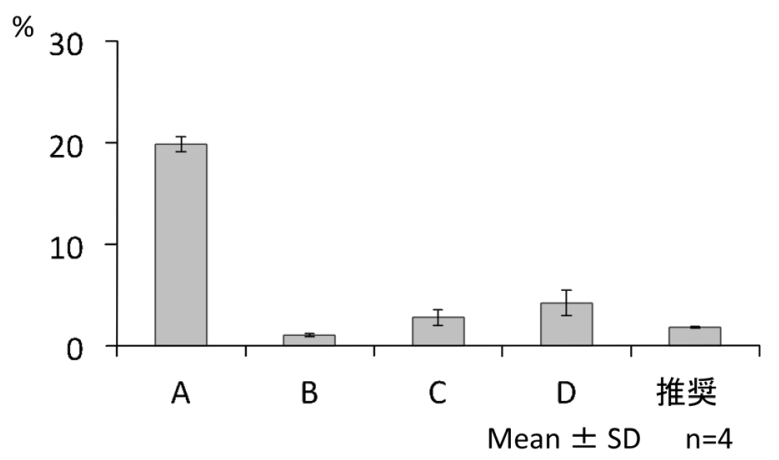

反発指数

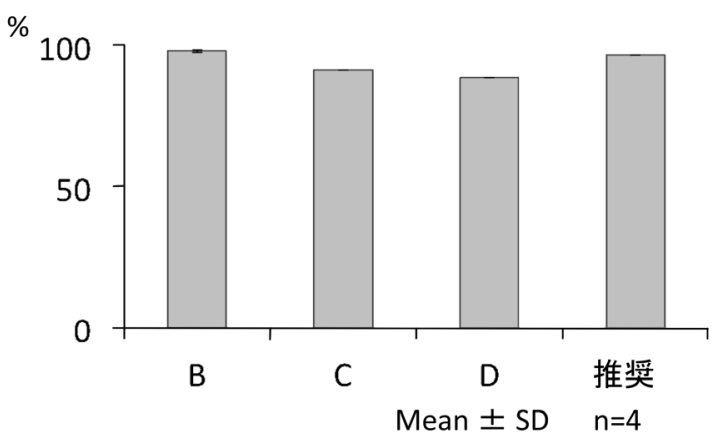

注: 推奨ガウンと比較して, すべてのガウンでp<0.01 ガウンAの反発指数は測定不可

図 6 各ガウンのパクリタキセル注射液に対する浸透指数および反発指数 推奨ガウンを基準として，それぞれのガウンのPTXに対する耐液体浸透性および反発性を比較した。 グラフは平均值士標準偏差で示し, 危険率 $1 \%$ 以下を有意差有りとした。 ガウン A の反発指数は PTX が完全に透過してしまい, 評価不可能であった.

污染時にはただちに交換することとされている. 今回用いたガウンは，すべて撥水加工されている が，持続耐浸透性試験では推奨ガウンと同等に 5-FUの湿潤および透過を防護できたガウンはな く，ガウン A および D では 3 時間後までに 5-FU が検出された。 また，推奨ガウンを含め 8 時間後 にはすべてのガウンでごく微量の 5-FU が検出さ れ，推奨ガウンでも，3 時間を超えて使用するこ
とは危険であることが考えられた。また，PTX に対しては, ガウン AおよびDは完全に透過させ た. ガウン $\mathrm{B}$ は重量変化のみでは推奨ガウンと 同等であったが，3時間後にはろ紙への PTX 透 過が認められた. ガウン C はばらつきが大きく 1 時間後より推奨ガウンと比べて有意に透過量が高 く，ろ紙への透過が検出された。このように，両 薬剂に対し 3 時間を超えて推奨ガウンと同等の透 
過量を維持できたガウンはなく，調製時に抗がん 剂の付着に気づかなかった場合に被曝の危険性が 示唆された。 さらに, ガウン Cでは PTX の湿潤 率が特に高かった。これは, ガウン $\mathrm{C}$ は 3 層性 不織布であり，二層目にポリエチレン製で薬剤不 透過性の層を含んでいるため, 外側の層で PTX を吸収し，二層目で透過を阻止したが，時間経過 とともに徐々に透過したと考えられる. 以上より， ポリエチレンでコーティングされたガウンなど の，表層に重要な素材が使用されているガウン以 外では, たとえ 4 層性で厚い生地, 耐アルコール 加工または耐油加工の生地であっても, PTX な どの油脂性溶媒を用いた注射剤はガウン生地へ付 着と同時に湿潤，透過することから，污染時にた だちに交換することを徹底しても，防護には不適 切であることが考えられる. しかし，推奨ガウン においても，ガウンまたはろ紙の重量変化が認め られた．今回の実験では試験液の蒸発やろ紙への 吸湿等による重量変化への影響を考慮していない ため, 万紙やガウン生地の吸湿が原因の 1 つと考 えられる. 特に, PTXでの湿潤率が高值であり, アルコールの蒸発とろ紙へ吸収が影響していると 考えられる.

さらに, 反発性試験の結果, 5-FUに対しては, ガウン A 以外は $98 \%$ 以上の反発指数を示してお り，透過もほとんど認められなかった。作業領域 の抗がん剤污染を調查した研究では，抗がん剂を 取り扱った領域以外からも検出されている?"。 そ のため, 污染されたガウンを脱ぎ去る際，または, 作業中であっても, 薬液に対する反発性が高いガ ウンは，皮膚だけではなく作業区域を污染する可 能性が考えられ, 脱衣時に細心の注意が必要とな る。一方, PTX に対する反発指数はガウン B お よび推奨ガウンが $96 \%$ 以上の反発指数であり, 皮膚または作業区域を污染する危険性が考えられ るが，5-FUに対する反発性と比べると，ガウン への湿潤または付着が多かった，今回の実験系で はガウン生地面積に対する試験液量が多いため, ガウン上に留まらずに流れたが，PTX は 5-FUに 比べ粘性が高く，ガウン生地上に留まりやすいと 考えられる。 また，ガウン $\mathrm{C}$ はガウン $\mathrm{B}$ および 推奨ガウンと同様に浸透はほとんど認められな
かったが, 反発指数はガウン Bおよび推奨ガウン が 98.2\%および 96.7\%に対し，ガウンCは $91.4 \%$ と低く，ガウン内への湿潤が考えられる。また, ガウン D は持続耐液体浸透性試験では PTX が完 全に浸透したが， $88.7 \%$ の反発指数が認められ， 浸透指数は他のガウンより高い傾向があった，そ のため, 短時間であれば防護することは可能であ るが,すぐに浸透し被曝する危険性が考えられる。 しかし, ガウン C および D は持続耐液体浸透性 試験結果からも, 試験液滴下直後よりガウンに湿 潤し，湿潤しきれなかった試験液が流れたと考え られ，実際は反発していないと思われる。なお， ガウン A は PTX が完全に浸透し, 反発指数の測 定が不可能であり, 浸透指数もほかのガウンと比 べ明らかに高く，防護することは不可能であると 思われる。 以上より, ガウン生地の反発性は, 防 護するうえで必要な性能であるが，ガウンの交換 時の皮虐への被曝の危険性や作業領域の污染の問 題を考慮すると, 付着した薬剤をガウン上に留め ておくことができ, 薬剤を透過させない素材が適 切であると考えられる.

抗がん剂被曝の危険性に関しては, Sessink ら が cyclophosphamide において, 1 日 $0.18 \mu \mathrm{g}$ の被 曝により，100万人の医療従事者あたりの年間の 追加発がん率は 1.4 人から 10 人であることを報 告しており ${ }^{8)}$, ごく微量の被曝でも長期的な曝露 により危険を及ぼす可能性があることが考えられ る。また，薬剤師は抗がん剤を原液のまま扱うこ とが多いため, 微量の被曝であっても重大な健康 障害を生じる可能性がある，抗がん剂を扱う看護 師において, 最小限の防護具を装備した群はコン トロール群に比べ, リンパ球数において有意差が 認められたことの報告があり ${ }^{9}$, 適切な防護対策 を行うことで，職業性抗がん剂被曝を低減化でき ると考えられる。しかし, コストの問題等もあり， 適切に防護具を使用していない施設も数多くある ことから, 適切な保護具の普及や施設内での体系 的な管理体制を構築することが必要である. 


\section{引用文献}

1）社団法人日本病院薬剂師会, “注射剤·抗がん薬 無菌調製ガイドライン”, 薬事日報社, 東京, 2008, pp.23-79.

2) Yoshida J, Kosaka H, Nishida S, Kumagai S, Actual conditions of the mixing of antineoplastic drugs for injection in hospitals in Osaka Prefecture, Japan, $J$ Occup Health, 2008, 50, 86-91.

3) 杉浦伸一, 伊東亜紀雄, 谷村学, 中西弘和, 橋田亨, 濱敏弘, 宮川真澄, 森健司, 学術委員会学 術第 3 小委員会, 注射剤の安全使用に関する研 究 抗がん剂調製時の被曝污染防止に関する研 究,日本病院薬剤師会雑誌, 2010, 46, 23-24.

4）吉田仁, 熊谷信二, 吉田俊明, 宮島啓子, 甲田茂樹, 医療従事者への抗がん剤ばく露とリスクアセス メント手法の確立 第二報 チェックリストと安 全作業マニュアルの提案とその検証, 労働安全 衛生総合研究所特別研究報告, SRR-NO. 40, 2010, 135-148.

5) Connor $\mathrm{TH}$, An evaluation of the permeability of disposable polypropylene-based protective gowns to a battery of cancer chemotherapy drugs, Applied Occupational \& Environmental Hygiene, 1993, 8, 785-789.
6) Harrison BR, Kloos MD, Penetration and splash protection of six disposable gown materials against fifteen antineoplastic drugs, J Oncol Pharm Pract, 1999, 5, 61-66.

7) Sessink PJM, Boer KA, Scheefhals APH, Anzion RBM, Bos RP, Occupational exposure to antineoplastic agents at several departments in a hospital. Environmental contamination and excretion of cyclophosphamide in urine of exposed workers, Int Arch Occup Environ Health, 1992, 64, 105-112.

8) Sessink PJM, Kroese ED, van Kranen HJ, Bos RP, Cancer risk assessment for health care workers occupationally exposed to cyclophosphamide, Int Arch Occup Environ Health, 1995, 67, 317-323.

9) Burgaz S, Karahalıl B, Bayrak P, Taskın L, Yavuzaslan F, Bökesoy I, Anzion RBM, Bos RP, Platin N, Urinary cyclophosphamide excretion and micronuclei frequencies in peripheral lymphocytes and in exfoliated buccal epithelial cells of nurses handling antineoplastics, Mutation Research, 1999, 439, 97-104. 